\title{
Breeding and Fecundity in a Subterranean Mysid, Lepidomysis longipes (Pillai and Mariamma)
}

\author{
by
}

\author{
C.N. NATH*
}

\section{INTRODUCTION}

Lepidomysis longipes inhabits freshwater wells of Kottayam, S.India. It gains entrance into the wells from the water bearing subterranean channels (Nath and Pillai, 1972). During the course of a year long study of this animal, vis-a-vis its breeding and fecundity, it was found that it shows some peculiar features, very different from its epigean relatives. The results of these observations form the subject matter of this paper.

\section{MATERIAL AND METHODS}

The mysids were collected at monthly intervals from the well employing the method described by Nath and Pillai (1972). This entails stirring the water in the well by drawing a bucket vertically in and out of the water column successively for five minutes. This is presumed to effect a thorough mixing of the bottom detritus with the contained animals with the water. The water is then drawn out in known quantities and the animals are collected. These were grouped into four categories, based mainly on the degree of development of the secondary sexual characters. This classification is a slight modification of the one adopted by Mauchline (1965) for the study of the littoral mysids of the British shores. In the absence of females with marsupia from which young have emerged in the present collection, this division of Mauchline's classification has been omitted. Likewise, males have not been classified into mature and immature forms.

The four groups in the classification of the mysids collected are:

1. juveniles without any secondary sexual characters,

2. males with setal blocks on the third segment of the thoracic appendages 6 to 8 and penial lobe on the base of the eighth thoracic appendage,

3. females with developing oostegites but with no egg or embryo in the brood pouch and,

4. females with eggs or embryos in the brood pouch.

* Govt. P. G. College, Mandsaur, M.P., India. 


\section{BREEDING}

Berried females appear for the first time in the well population by December. On the strength of this fact, it can be stated that breeding begins in December. It reaches its peak intensity by March as evidenced by a large percentage of berried females in the well population. The breeding ends abruptly in April when no more berried females are to be noticed in the well.

A glance at the histogram (fig. 1) shows that the juveniles of smaller sizes are no more to be seen in the well population from September. Evidently, the juveniles have grown beyond these size classes by this time.

By October there is sudden reappearance of these forms and they form a large percentage of the population. These must constitute fresh releases from brood pouches. However, even after the appearance of these juveniles, berried females do not appear in the well population. The question naturally arises as to where they are. They appear in the well population only as late as December. The only plausible explanation appears to be that the females that gave rise to these new arrivals (juveniles) are still a part of the subterranean population and that the berried females start appearing in the well population only when the breeding activity reaches maximum intensity. It may be noted that the juveniles of size class I appear in November too, even though there are no berried females in the population of that period or of the immediate previous period. This fact appears to strengthen the above inference that the berried females start appearing in the well population only when the breeding activity attains maximum intensity. There appears to be a pause in the reproductive activity, because there are no fresh additions to size class I in December. This pause appears sometime in October, because development is completed by the egg in about three months.

It has been noticed that adult females and males of the well population in the reproductive periods disappear in September and October from the well. It appears that they reenter the subterranean channels, where probably the breeding season is set in motion. However, there is no positive evidence to support this contention, though work is in progress to solve this mystery.

Thus, it is evident that the breeding season of Lepidomysis longipes extends from December to April and the maximum intensity of breeding activity is in March, when the largest percentage of berried females are found in the population (Graph). A short secondary reproductive period is evident in August and September and this appears to be passed through in the subterranean channels.

\section{FECUNDITY}

These mysids are remarkable for the limited number of eggs laid by them and for the considerably, long period of development of the embryos. Pillai and Mariamma (1964) reported that the brood pouch of the animal contains usually nine eggs at a 


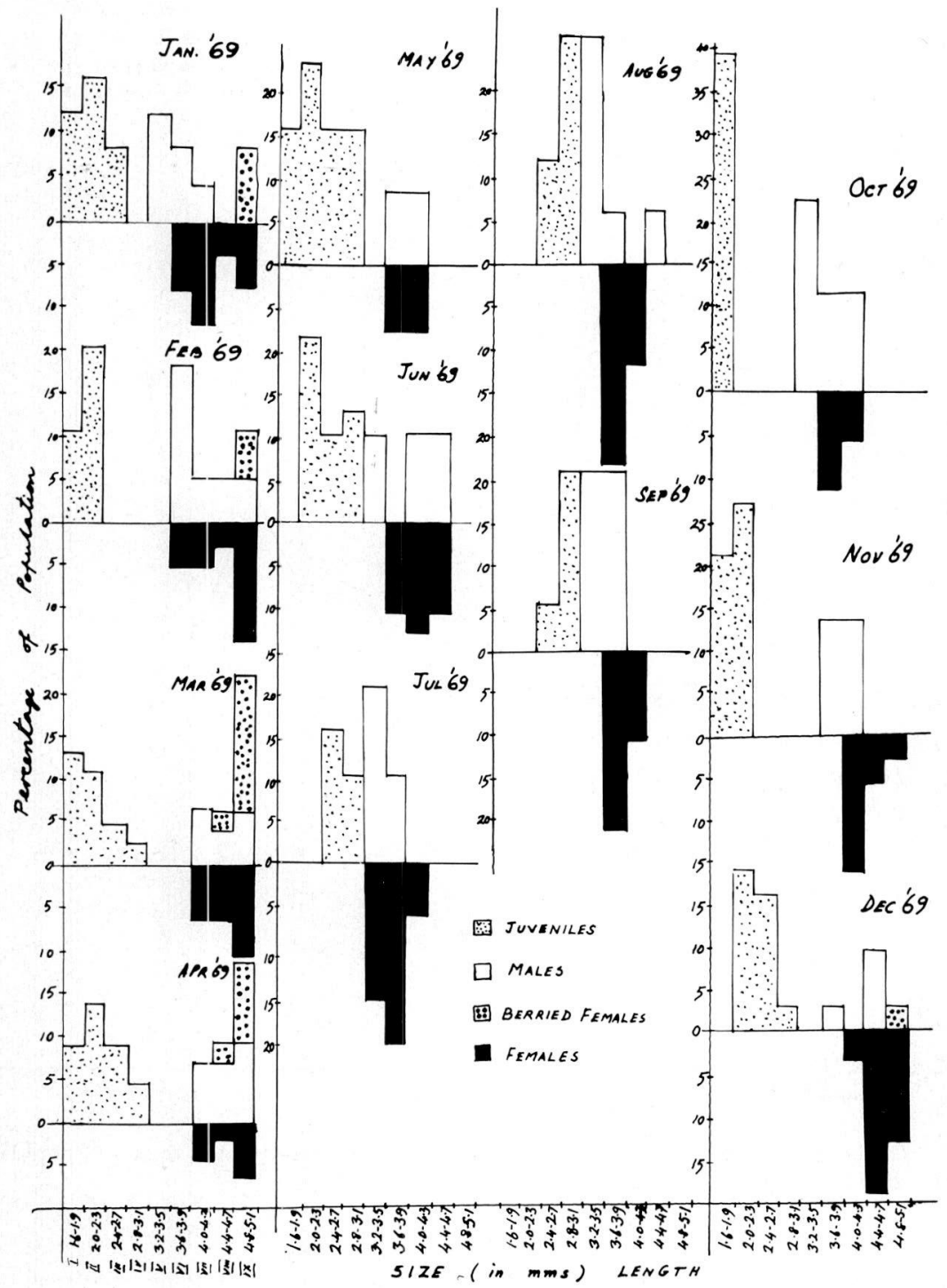

Fig. 1. Lepidomysis longipes(Pillai \& Mariamma). Histogram representing the results of population studies. 


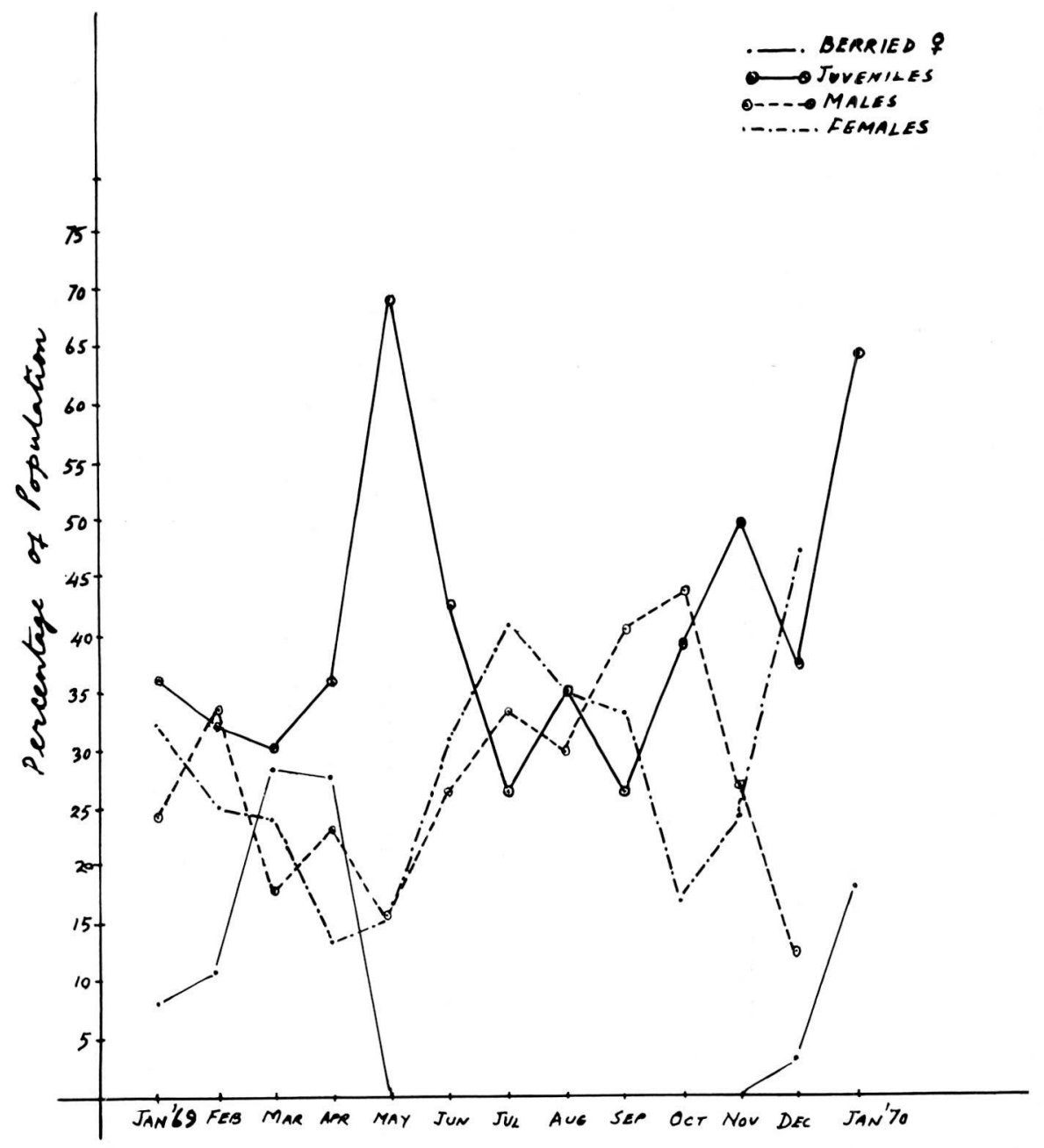

Fig. 2. Lepidomysis longipes(Pillai \& Mariamma). Graph representing the results of population studies.

time. In the present study also the maximum number of eggs noticed was nine, though the number was found to vary between seven and nine. This low fecundity of the animals is to be attributed to the deficiency in food in the subterranean channels, which form the original home of these mysids. Similar observations of low fecundity have been made by other authors also in cavernicolous animals. Pop (1968) working on cavernicolous lumbricides found that the reduction in number and size of the gonads is characteristic of forms existing in soil deficient in food. 
The well habitat of the mysid under study has been shown by Nath and Pillai (1972) to be deficient in food.

That these animals breed only once in a year appears evident from the fact that the ovary of the berried females appear clear, transparent and empty, devoid of developing ova. In epigean forms like Praunus inermis, Blevgad (1922) observed berried females to "have in their ovaries well developed eggs of a size comparable to the newly laid eggs and that they are thus going to breed once more",

\section{SUMMARY}

The hypogean mysid, Lepidomysis longipes has a breeding period extending from December to April with the peak period in March. A secondary breeding period appears in August and September. The females have low fecundity and carry a maximum of nine eggs. Development is delayed due to lack of nourishment in the environment. The mysids breed only once a year.

\section{RESUME}

Le Mysidacé hypogé Lepidomysis longipes a une période de reproduction qui s'étend de décembre à avril, avec un maximum en mars. Une période accessoire de reproduction existe en août-septembre.

Les femelles ont une faible fécondité et portent 9 oeufs au maximum. Le développement en est retardé par suite du manque de nourriture dans le milieu. Ces Mysidacés se reproduisent une seule fois par an.

\section{ACKNOWLEDGEMENTS}

The author is deeply indebted to Dr. N.K. Pillai, Reader, Marine Biology Laboratory, Trivandrum-7, for the kind help and guidance he offered in undertaking the present study.

\section{REFERENCES}

BLEVGAD, H. 1922. On the biology of some Danish gammarids and mysids. /Gammarus locusta, Mysis flexuosa, Mysis relicta, Mysis inermis). Re. Danish Biol.St.Copenhagen, 28:pp.1-103.

MAUCHLINE, J. 1965. Breeding and fecundity of Praunus inermis (Crustacea, Mysidacea). J.Mar.Biol.Ass. U.K., 45: pp.663-671.

NATH, C.N. and N.K. PILLAI. 1972. On the food and feeding habits of Lepidomysis longipes (Pillai \& Mariamma) (Crustacea, Mysidacea). Int.J.Speleol., 4:45-50.

POP, V. 1968. Les Lumbricides cavernicoles de la collection Biospeologica. Arch.Zool.Expér. et Gén., 109: 2, pp.229-256. 